\title{
Students' View on the ICT Courses Specially-Designed for the Deaf Learners
}

\author{
Norazah Nordin ${ }^{1}$, Rozniza Zaharudin ${ }^{2}$, Mohd Hanafi Mohd Yasin ${ }^{1} \&$ Maimun Aqsha Lubis ${ }^{1}$ \\ ${ }^{1}$ Faculty of Education, Universiti Kebangsaan Malaysia, Selangor, Malaysia \\ ${ }^{2}$ School of Educational Studies, Universiti Sains Malaysia, Malaysia \\ Correspondence: Norazah Nordin, Faculty of Education, Universiti Kebangsaan Malaysia, 43600 UKM Bangi, \\ Selangor, Malaysia. E-mail: norazah13140@yahoo.com
}

\author{
Received: August 1, 2013 Accepted: August 16, 2013 Online Published: August 30, 2013 \\ doi:10.5539/ass.v9n12p13 URL: http://dx.doi.org/10.5539/ass.v9n12p13
}

\begin{abstract}
Internet and Computers have become requirements of life, mainly because they present a doorway into the World Wide Web. This World Wide Web that delivers an online learning platform is a very essential technology. Therefore, the accessibility issue in Web applications is very crucial, particularly for the Deaf Learners. The main objective of this research is to study the Deaf Learners' satisfaction and interests in the developed e-learning platform named e-HearMe, which offers ICT courses that are specially designed for these learners. This research applied the quantitative method, whereby a questionnaire for the students' that acts as the research instrument was distributed to 3 schools. These 3 schools were selected as research locations for their ICT Courses that are offered for the Deaf, for the whole of Malaysia. Thus, a total of 72 Deaf Learners from the Higher Secondary Level of Form 4 and Form 5 are chosen as the research sample. In evaluating the questionnaires' results, the students were satisfied with the existence of this online e-learning medium $e$-HearMe, stating that they could share and exchange knowledge of information on the various ICT courses, with other teachers and other students from all over Malaysia, regardless of educational purposes or social purposes.
\end{abstract}

Keywords: $e$-HearMe, ICT courses, E-Learning, the deaf learners

\section{Introduction}

Internet has become a crucial requirement in life, mainly because it presents a doorway into the World Wide Web. This World Wide Web that delivers an online learning platform is a very essential technology, combining with computers. Therefore, the accessibility issue in Web applications is very crucial, particularly for the Deaf Learners. The speedy-growth of Web evolutions on web accessibility has also encouraged teachers to apply this theme in online-courses. It is very significant for society to contain the right and ability to use any software, hardware or any assistive technologies to fully understand and interact with the website content, without considering the disability, language barriers, geographical location, or other impairing factor.

Learning ICT is crucial in the deaf learners' development, thus learning ICT Education online (e-learning) also enable them to expand their learning styles. Learning online can be defined as the Learning Education conducted through the computer technology medium. It is very crucial that these virtual learning environments, and other educational e-learning applications technologies to be accessible to all individuals; particularly in this study, the Deaf Learners. In this paper, we explored the Deaf Learners' interests on the various ICT courses (Information Communication Technology courses) held through e-learning.

\section{Background}

Higher education for the deaf learners in Malaysia is an imperative part of development for a country's nation. The higher education will allow the deaf learners to attain the necessary skills and knowledge for social survival in the world of employment. A disabled individual is integrated in an environment as natural as possible, as defined in Education in a fully inclusive model. But for the Deaf learners, the disability to detect low-amplitude sounds or frequencies, where they could not perceive sounds due to their loss of hearing. The hearing loss affects both the ability to receive and produce spoken language. Hence it is quite common for the deaf learners to struggle with spoken and written language, as their speech acquisitions are poor. Thus, the Sign Language is used by them to communicate with one another. Sign Language is the most convenient and efficient 
communication tool for the deaf learners. In higher education universities, many faculties provide the students and staff with interpreters who are fluent in both signing and speech, for the deaf learners.

In Malaysia, ICT Education has become a more and more popular major in higher education, for all types of individuals, regardless the normal individuals or the disabled individuals. Courses like Multimedia, Computer Graphics, Web-Design and 3D-Animation are the examples. Academicians teaching ICT courses must ensure that the disable individuals have full access to computer tools and applications. Moreover, with the current trend towards teaching Graphical User Interfaces (GUI), this must suit the Deaf Learners as well. The continuous computer development has made ICT technology becomes progressively more crucial in education. The Computing Education field offers high-paying challenging careers which are more accessible for the deaf learners. Computing careers are potentially offered to deaf learners because of its advancements in assistive technology that offer access to computers. Moreover, ICT provides more opportunities for the deaf learners in Malaysia, since most jobs were opened via the ICT industry. With computers, many career opportunities are open for the deaf learners. There is a wide acknowledgment that computing innovation requires a diverse workforce, such as systems designers, software developers, technology teachers, information systems analysts, computing faculty, and other professionals.

ICT courses are crucial for the deaf learners. The use of sign language to teach the deaf learners are needed and the interpreters could be available in the classroom too. There are many supported visual media aids like graphics, tables and charts that can be used in computer education for the deaf learners, as they have to depend more on their vision, due to their loss of hearing. Additionally, in the operating software system, the visual display is vital for the deaf learners, as only the visual displays can help the deaf learners to understand a particular task. Computer education is suitable for the deaf learners, as computers are deaf-friendly, and very much adaptable to the deaf learners. Due to their visual concentration, most deaf learners are skilled in drawing and designing graphics, hence they excel well in fields like Web Design, Visual Arts and Graphics Animation. This perspective is suitable for the deaf learners as it studies how they interact with the computer to access the learning materials online.

\section{Research Methodology}

This study had used the questionnaire, mainly to collect a huge amount of data from students, with the objective to seek their satisfaction and feedback (towards the developed e-learning e-HearMe), to understand the relationship among the students with the computers usage and most importantly, to explore the level of interest of these students in the designed ICT courses, mainly the Computer Graphics course (via the e-learning platform, $e$-HearMe). With this questionnaire, feedback from the Hearing-Impaired Individuals was gathered.

This study was carried out in 3 research locations, which are Terengganu, Negeri Sembilan and Johore. These 3 research locations were chosen from the whole of Malaysia, as they are the higher secondary schools of Form 4 and Form 5 that offer Computer Graphics course to the deaf learners. Hence, these 3 schools are selected as the location of data collection.

\subsection{Research Sample and Data Collection}

The research sample participated in this study were the Deaf Learners of Form 4 and Form 5, and the respondents were divided into two groups, which were form 4 students, and the form 5 students. Both groups have enrolled in the Computer Graphics class.

For the Data Collection Method, 3 schools were selected from the whole of Malaysia, which executes the Hearing-Impaired Education Program (offering Computer Graphics Course). Researcher started the research from Kuala Terengganu, then headed to Negeri Sembilan, and ended with Johore. All data collection methods are done on weekdays, and it took several months to complete the whole process. It will take several days for the students to complete the questionnaires. For the 'e-HearMe' e-learning portal Intervention sessions, the lessons are carried out in accordance to the class time-table, when the Computer Graphics subject is being taught for a particular session. The duration of this course approximately took around two weeks for each school; hence altogether 6 weeks were taken to complete all 3 schools. The face-to-face learning approach was taken place in carrying out the lessons in the schools, whereby the students tries out the E-Learning portal

\subsection{Research Instrument}

For this study, the instrument used was a set of questionnaire, consisting two techniques which are the fixed scaling response (set by the researcher based on the study reading), and the open-ended questions. The Open-ended questions give the students (as respondents) a wider space to justify their opinions freely. The questions set in the questionnaires are simple and that do not have many words other than the intended 
explanation needed.

This questionnaire was a follow-up from the earlier research conducted [14-19], to seek feedback as a result of the E-Learning Portal that has been developed. This questionnaire mainly seeks to explore on the levels of knowledge, use, satisfaction, and most importantly the interests of the Hearing-Impaired students, towards the Computer Graphics course. The aspects of these questionnaires were analyzed in accordance with the problem stated earlier. Simultaneously this questionnaire also focused on helping us in improving and upgrading the existing content of the Computer Graphics Course that was already offered in some selected schools for the Hearing-Impaired Education Program.

There are 6 parts embedded in the questionnaire which are; Background information on the students (part I), General information on Computers (part II), Interface and Multimedia Criteria of the Portal (part III), Information Content (part IV), Computer Graphics Course (part V), and the Opinions/Suggestions (part VI).

Part I consists of the demographic data like sex, age, race, form, state, name of school, and favourite course in school. Part II to Part V are questions that are in statements forms, based on the Likert Scaling Scores Values, which respondents had circled (1-5) for each item provided. The 5 answers to these questions are based on the respondents' knowledge, experiences and feelings; which are; 1 (if respondents strongly disagree), 2 (if respondents disagree), 3 (if respondents are not sure), 4 (if respondents agree) and 5 (if respondents strongly agree). Only at the last part, which is Part VI, is the open-ended questions whereby respondents can state their own answers freely.

\section{Findings}

A total of 72 Deaf Learners participated in this study, consisting of 25 male students (34.72\%), and 47 were female students $(65.28 \%)$. The number of students in this study was from Form 4 which are $30(41.6 \%)$, and Form 5 which were 42 (58.4\%) respectively. For the race category, 45 students $(62.5 \%)$ were Malay respondents, 25 students $(34.72 \%)$ were Chinese respondents, and 2 students $(2.78 \%)$ were Indian respondents. For the state category, 38 students $(52.8 \%)$ were respondents from Johore, 14 students $(19.4 \%)$ were respondents from Terengganu, and 20 students $(27.8 \%)$ were respondents from Negeri Sembilan.

Table 1 clearly shows that almost $85 \%$ of the students understood how to use the E-Learning portal shown to them, as meaningful information can easily be understood in the Portal E-HearMe, which is related to the Hearing-Impairment. On the question whether The Portal E-HearMe was satisfying, in the sense whether it does provide information fulfilling the requirements and criteria for the Hearing-Impaired students, from the 72 respondents who are involved answering this questionnaire, 60 respondents answered Strongly Agree (83.3\%), 8 respondents answered Unsure (11.1\%), and another 4 respondents answered Disagree (5.6\%). The students claim that the Portal was easy to understand and obtaining information was straightforward.

Table 1. The information content of portal 'e-HearMe'

\begin{tabular}{|c|c|c|c|c|c|c|c|}
\hline & & Strongly Agree & Agree & Unsure & Disagree & Strongly Disagree & Total \\
\hline $\mathbf{N}$ & Valid & 60 & $\mathbf{0}$ & 8 & 4 & $\mathbf{0}$ & 72 \\
\hline$\%$ & & 83.3 & 0 & 11.1 & 5.6 & 0 & 100 \\
\hline
\end{tabular}

Based on the 72 students who are involved answering this questionnaire, 70 respondents answered Agree (97.2\%), nobody answered Unsure, and another 2 respondents answered Disagree (2.8\%), on the question of whether the Computer Graphics learning materials provided in The E-Learning e-HearMewas easy to understand. This shows that around $97 \%$ of the students had no problem with understanding the embedded learning materials, compared to the other $3 \%$ who disagreed, as they claimed to have stumbled upon some problems. This is shown in Table 2. The students claim that having the Computer Graphics learning materials via e-learning has made it easier for them to access and obtain. They agreed on the necessity to have these learning materials of computer graphics to be available online, as it can be accessible anytime, anywhere. 
Table 2. Computer graphics learning materials was easy to understand

\begin{tabular}{|c|c|c|c|c|c|c|c|}
\hline & & Strongly Agree & Agree & Unsure & Disagree & Strongly Disagree & Total \\
\hline $\mathbf{N}$ & Valid & 70 & $\mathbf{0}$ & 2 & $\mathbf{0}$ & $\mathbf{0}$ & 72 \\
\hline$\%$ & & 97.2 & 0 & 2.8 & 0 & 0 & 100 \\
\hline
\end{tabular}

Table 3 shows the category of Interface Criteria, on the question whether the E-Learning Portal E-HearMe was user-friendly, in the sense whether it does provide an easy understandable navigation and links, fulfilling the requirements and criteria for the Hearing-Impaired students vision'; all students answered Agree (100\%), claiming that this eases the Hearing-Impaired Students' to be interested in the E-Learning Portal E-HearMe, as the Portal is not complicated, and the limited-yet-concise menu were compatible with the Hearing-Impaired needs, and it was not confusing. Again, although this brings a total of $100 \%$, however some suggestions were raised, like they wish to see more colourful images to be inserted into the E-Learning Portal E-HearMe, so that it could be much more attractive for the Hearing-Impaired. However, due the limitations of using Moodle, users can only chose a specific template design, hence the ability to design the layout of the E-Learning Portal E-HearMe is hindered. This category of 'Interface (User-Friendliness)' is clearly shown in Table 3.

Table 3. The interface criteria of the 'e-HearMe'

\begin{tabular}{|c|c|c|c|c|c|c|c|}
\hline & & Strongly Agree & Agree & Unsure & Disagree & Strongly Disagree & Total \\
\hline $\mathbf{N}$ & Valid & 60 & 12 & $\mathbf{0}$ & $\mathbf{0}$ & $\mathbf{0}$ & 72 \\
\hline$\%$ & & 75 & 25 & 0 & 0 & 0 & 100 \\
\hline
\end{tabular}

Table 4 shows the category of Multimedia Elements, on the question whether the E-Learning Portal E-HearMe was fully embedded with the multimedia elements of colours, texts, images, videos, (no audios required), assisting the understanding of the Hearing-Impaired students; all students answered Agree (100\%), claiming that this eases the Hearing-Impaired Students to be interested in the E-Learning Portal E-HearMe, as the Portal does catches the vision of the Hearing-Impaired. However, the same suggestions as shown in Table 3 were raised.

Table 4. The multimedia elements of the 'e-HearMe'

\begin{tabular}{|c|c|c|c|c|c|c|c|}
\hline & & Strongly Agree & Agree & Unsure & Disagree & Strongly Disagree & Total \\
\hline $\mathbf{N}$ & Valid & 55 & 17 & $\mathbf{0}$ & $\mathbf{0}$ & $\mathbf{0}$ & 72 \\
\hline$\%$ & & 76.4 & 23.6 & 0 & 0 & 0 & 100 \\
\hline
\end{tabular}

In Table 5, for the questionnaires on the students' understanding whether the Computer Graphics Notes (with more visual graphical images) provided were able to increase their performance in the selected course, majority of the answers were 'Strongly Agree' and 'Agree'. This can be seen in Table 5:

Table 5. Computer graphics learning materials (with more visual graphical images) does increase students performance in understanding

\begin{tabular}{|c|c|c|c|c|c|c|c|}
\hline & & Strongly Agree & Agree & Unsure & Disagree & Strongly Disagree & Total \\
\hline $\mathbf{N}$ & Valid & 52 & 12 & 8 & $\mathbf{0}$ & $\mathbf{0}$ & 72 \\
\hline$\%$ & & 72.2 & 16.7 & 11.1 & 0 & 0 & 100 \\
\hline
\end{tabular}

\section{Discussion}

The Hearing-Impaired Students studying the 'Computer Graphics' course from the Higher Level Secondary School (Form 4 and Form 5) raised their opinions. From the findings mentioned earlier, it is proven that the Hearing-Impaired Individuals are strongly interested in the Computer Graphics course, since they were really excited in exploring E-HearMe, going through the learning materials online, and trying out the exercises given. 
It was rather a challenge for them going through this process by themselves, without the teachers' supervision (as it is online-learning), however when being asked, the Hearing-Impaired Students really enjoyed the embedded Computer Graphics course in the e-HearMe e-learning portal. They claimed the courses had contained more graphical elements compared to the black and white lengthy-sentences graphic-less learning materials handed to them in the traditional class [10].

Hence, the connection between the results of their interest in learning Computer Graphics, and their disability to hear; does motivate an approach to offer Graphics courses that could focus more on their vision. In other words, courses which catch their vision more, having attractive images are a great factor for these Hearing-Impaired students.

Relating to a research by Zawolkow [11], the study shows that students learning through computer-assisted instruction learn more effectively with computer aid, than without it. In contrast to textbooks, which are restricted to static graphics, e-learning modules can use animated and interactive graphics for visualizing purposes, as it is vital for understanding the material offered online.

To be exact, when being asked whether do they enjoy having this Computer Graphics course offered Online (via E-HearMe E-Learning Portal), their answers were optimistic, giving average responses they are able to learn these courses Online, anytime and anywhere. The most important aspect they highlighted was; they are able to learn the courses at their own pace. The Learning materials do help them to self-study, and try the exercises at any given time, and this is quite challenging for them.

In contrast, some answers given were respondents pessimistically. For instance, due to the lack of understanding on the lengthy word; they dread the thought of unable to follow the learning materials online. Some of the respondents gave explanation that they are very much interested in this Computer Graphics course, however if it is online, they see it as a big challenge that they can't understand as easy as they do in class, as the teachers are unavailable to interpret the sign-language to them. This problem does not only affect the students' understanding, but it also affects the whole idea of learning this course by themselves, without any supervision from the teachers. Hence, it de-motivates them to continue.

To support this, Bueno 2007 also did a research on Content Adaptation for the Deaf, where reading comprehension was a problem for the Deaf [12]. They proposed to solve the problems that Hearing-Impaired students faced when reading a text (printed, downloaded from an e-learning site), and a study on their needs when studying an e-learning course. Hence the teachers see this as an issue if the students are not able to understand the content.

Since there were only three schools that offer Computer Graphics Course in their school, when being asked their view on having this course online via E-Learning Portal E-HearMe, so that the course can be shared with other Hearing-Impaired students (schools that do not offer the Computer Graphics course), the respondents showed very high positive support. They give reasons like it gives opportunities for other non-ICT schools to learn these ICT courses (online), since they were not given a chance to learn them in school. High demands to have this course available online (via E-Learning), was resulted in positive form, to help the students with tutorials, etc. They were very positively determined to learn them virtually.

Relating to a research mentioned, Drigas (2004) alleged that the Hearing-Impaired Individuals deserve equal rights for their access and real attendance in the professional training. This was claim in a paper presenting the creation of a distance and life-long training Environment for the Hearing-Impaired Individuals in the e-commerce and new technologies sector via e-learning tools [13]. With this e-learning passage, these individuals can enter the new professional fields via their training with specialized knowledge in the use of the continuously developing technology sectors of e-learning and electronic Trade, also known as e-commerce.

\section{Conclusion}

In conclusion, the evaluation results from the Students' Perspective showed that most students were satisfied with the Computer Graphics Course embedded in the E-HearMe E-Learning Portal. Having ICT courses online (E-Learning), really helped them to learn the courses at their own pace, as they could accessed it online, anytime, anywhere. This is benefit for the schools that do not have ICT courses offered to them at all, as now they are able to learn this course online. Based on the problem statement earlier, since some students do wish to have the Computer Graphics course taught in their schools, now they can learn them via this E-Learning Portal E-HearMe.

An equal learning should exist for all the hearing-impaired students, in Malaysia, as this will give opportunities for the hearing-impaired individuals to enable them master the computer proficiency too; and simultaneously 
develop each potential. ICT Courses should not be divided unfairly to only certain schools, and not for the entire community of The Hearing-Impaired, as this will only affect the confidence and faith of other hearing-impaired students that were not exposed to the ICT Education.

From the discussion gathered from the questionnaires conducted, many opinions were raised individually from the respondents. With regards to the ICT Education, computer courses were a demanding major and learning them online via E-Learning Portal E-HearMe was resulted in a positive form [14-19].

\section{References}

Bailey, C., \& Chambers, J. (1996). Interactive learning and technology in the US science and mathematics reform movement. British Journal of Educational Technology, 27(2), 123-133. http://dx.doi.org/10.1111/j.1467-8535.1996.tb00719.x

Beil, D. H., \& Panko, J. W. (1997). Educational Opportunities for the Deaf in Data Processing at Rochester Institute of Technology.

Boettcher, J., \& Conrad, R. M. (2004). Faculty Guide for Moving Teaching and Learning to the Web. League for Innovation in the Community College, Laguna Hills, CA, 2004.

Bolliger, D. U., \& Wasilik, O. (2009).Factors influencing faculty satisfaction with online teaching and learning in higher education. Distance Education, 30(1), 103-116. http://dx.doi.org/10.1080/01587910902845949

Bueno, F. J., Fernándezdel Castillo, J. R., Garcia, S., \& Borrego, R. (2007, June). E-learning content adaptation for deaf students. SIGCSE Bull, 39(3), 271-275. http://dx.doi.org/10.1145/1269900.1268862

Burgstahler, S., \& Ladner, R. (2006, June). An alliance to increase the participation of individuals with disabilities in computing careers. SIGACCESS Access. Comput. 85, 3-9. http://dx.doi.org/10.1145/1166118.1166119

Drigas, A. S., \& Kouremenos, D. (2005). An e-Learning Management System for the Deaf people. WSEAS Transaction on Advances in Engineering Education, 1(2), 20-24.

Mahshie, J. J., Vari-Alquist, D., Waddy-Smith, B., \& Bernstein, L. E. (1988). Speech Training aids for hearingimpaired individuals: III. Preliminary observations in the clinic and children's homes. Journal of Rehabilitation Research and Development, 25(4), 69-82.

Morrison, G. S. (2004). The Early Childhood Education Today, Pearson, NJ, USA, 2004.

Murakami, H., Minagawa, H., Nishioka, T., \& Shimizu, Y., (2002). Computer education and assistive equipment for hearing impaired people. TCT Education of Disabilities, 1(1).

Sierkowski, B. (2002). Achieving Web Accessibility. On SIGUCCS '02: Proceedings of $30^{\text {th }}$ ACM SIGUCCS conference on User services, pages 288-291. ACM Press, 2002. http://dx.doi.org/10.1145/588646.588725

Vanderheiden, G. C. (1997). Design for people with functional limitations resulting from disability, aging, or circumstance. In G. Salvendy (Ed.), Handbook of Human Factors and Ergonomics (2nd ed.). Purdue University. John Wiley and Sons, New York.

Zaharudin, R., Nordin, N., \& M.Yassin, M. H. (2011a). Online ICT-Courses Integrated For The Hearing-Impaired Individuals' Education: A Preliminary Study from the Teachers' Perception. The World Scientific and Engineering Academy and Society (WSEAS) Conference, Penang, Malaysia, 3-5 Oct 2011.

Zaharudin, R., Nordin, N., \& M.Yassin, M. H. (2011b). Online ICT-Courses Integrated For The Hearing-Impaired Individuals' Education: A Preliminary Study from the Students' Perception. International Conference on Informatics Engineering and Information Science (ICIEIS), Kuala Lumpur, Malaysia, 14-16 Oct 2011.

Zaharudin, R., Nordin, N., \& M.Yassin, M. H. (2011c). The Demand of ICT-Courses (via E-Learning) for The Deaf Learners. International Conference on LifeLong Learning (ICLLL), Kuala Lumpur, Malaysia, 14-16 Oct 2011.

Zaharudin, R., Nordin, N., \& M.Yassin, M. H. (2011d). Investigating Teachers' View on ICT-Education (Online-Learning) for the Deaf Students. International Conference on Education and Technology (ICET), Selangor, Malaysia, 6-8 Dec 2011.

Zaharudin, R., Nordin, N., \& M.Yassin, M. H. (2011e). Exploring Teachers' Insight on ICT Education via E-Learning for the Deaf Learners. The World Scientific and Engineering Academy and Society (WSEAS) Conference, Jakarta, Indonesia, 1-3 Dec 2011. 
Zaharudin, R., Nordin, N., \& M.Yassin, M. H. (2011f). Observation on the Deaf Students' Interaction in Learning ICT-Courses. The World Scientific and Engineering Academy and Society (WSEAS) Conference, Jakarta, Indonesia, 1-3 Dec 2011.

Zawolkow, G. (1980). Apples used in Education of Deaf Students. (re-printed with permission: Apple Application News, Issue 2, Feb 1980), Coordinator Computer-Assisted Instruction, Berkeley.

\section{Copyrights}

Copyright for this article is retained by the author(s), with first publication rights granted to the journal.

This is an open-access article distributed under the terms and conditions of the Creative Commons Attribution license (http://creativecommons.org/licenses/by/3.0/). 